\title{
Short Communication: \\ Curcuma wanenlueanga (Zingiberaceae), a new species of subgenus Curcuma from Thailand
}

\author{
SURAPON SAENSOUK ${ }^{1, \vartheta}$, THAWATPHONG BOONMA ${ }^{2}$, ADISAK THOMUDTHA ${ }^{3}$, PARIYA THOMUDTHA ${ }^{4}$, \\ PIYAPORN SAENSOUK ${ }^{5}$ \\ ${ }^{1}$ Plant and Invertebrate Taxonomy and Its Applications Unit Group, Walai Rukhavej Botanical Research Institute, Mahasarakham University. \\ Kantarawichai District, Maha Sarakham, 44150, Thailand. "email: surapon.s@msu.ac.th \\ ${ }^{2}$ Brio Botanical Research Garden. 53 M.5 Ban Mai Village, Phikun Ok, Ban Na District, Nakhon Nayok, 26110, Thailand \\ ${ }^{3}$ Thai Traditional and Alternative Medicine Division, Mahasarakham Hospital. Mueang District, Maha Sarakham, 44000, Thailand \\ ${ }^{4}$ Health Consumer Protection Sub-Division, Social Medicine Division, Mahasarakham Hospital, Mueang District, Maha Sarakham, 44000, Thailand \\ ${ }^{5}$ Plant and Invertebrate Taxonomy and Its Applications Unit Group, Department of Biology, Faculty of Science, Mahasarakham University, \\ Kantarawichai District, Maha Sarakham, 44150, Thailand
}

Manuscript received: 29 April 2021. Revision accepted: 28 June 2021.

\begin{abstract}
Saensouk S, Boonma T, Thomudtha A, Thomudtha P, Saensouk P. 2021. Short Communication: Curcuma wanenlueanga (Zingiberaceae), a new species of subgenus Curcuma from Thailand. Biodiversitas 22: 2988-2994. Curcuma wanenlueanga Saensouk, Thomudtha \& Boonma, a new species of Curcuma subgenus Curcuma (Zingiberaceae) from Thailand was described with detailed illustrations, and photographs. The dominant morphological description is terminal inflorescence, leaf adaxially green with reddishpurple along the midrib, leaf-sheath with reddish-brown tinge. Moreover, the color and smell rhizome of $C$. wanenlueanga has yellow with a darker core internally. It is distributed in Mae Hong Son Province, Northern Thailand, and cultivated throughout the country, i.e. Nakhon Nayok, Maha Sarakham, Chiang Mai, Tak, Chantaburi, Suratthani, and Kanchanaburi Provinces. It is used as Thai traditional medicinal. It grows in in sandy loam soil and well-drained in the mixed-deciduous forest, at elevation $700-900 \mathrm{~m}$ asl. It is accompanied by a revised key to 26 species of Curcuma subgenus Curcuma from Thailand.
\end{abstract}

Keywords: Curcuma, new species, Thailand, Zingiberaceae.

\section{INTRODUCTION}

The genus Curcuma L. is an important natural resource that provides many useful products from ancient times. As prescribed by Ayurveda, turmeric (Curcuma longa) has been used to treat sprains and swelling (Araujo and Leon 2001). Curcuma is one of the largest genera in the family Zingiberaceae, distributed from India to South China, Southeast Asia, Papua New Guinea, and Northern Australia (Larsen and Larsen 2006; Sirirugsa et al. 2007). The study of Záveská et al. (2012) supports the recognition of two subgenera within genus Curcuma namely subgenus Curcuma and Hitcheniopsis. They also suggest the recognition of a new subgenus Ecomata (LeongŠkorničková et al. 2015), proposed a new classification of subgenus, and also included some genera and species under the Curcuma, due to that the number of species of genus Curcuma in Thailand significantly increased.

Thailand is one of the diversity centers for Curcuma with all three subgenera and 66 species have been reported which 23 species belong to subgenus Hitcheniopsis, 18 species of subgenus Ecomata, and 25 species of subgenus Curcuma (Larsen and Larsen 2006; Sirirugsa et al. 2007; Saensouk et al. 2021). An undescribed species of Curcuma well known in the Thai vernacular name of "Wan-EnLueang" was found during the revision of the family
Zingiberaceae for the Flora of Thailand project. After comparing it with its allied ones, we found that this species did not match with any existing taxa, hence it is described and illustrated here as new species. A revised key to 26 species of Curcuma subgenus Curcuma in Thailand is provided for facilitating their identification.

\section{MATERIALS AND METHODS}

Plant materials were collected on 28 August 2017 from Mae Hong Son Province, Sob Moei District, $810 \mathrm{~m}$ above sea level, Boonma 60 (Figure 1) and the living specimens have been planted at Brio Garden in Nakhon Nayok Province and spirit specimens preserved in alcohol from Maha Sarakham Province, Mueang Maha Sarakham District, Thomudtha 1, 05.04.2021 (KKU) and additional specimens were also compared. The descriptions of morphologically similar species, Curcuma longa (Sabu 2006) and C. amada (Roxburgh 1810; Sabu 2006), and type specimens housed in various herbaria $(\mathrm{BK}, \mathrm{BKF}$, KKU, QBG) in Thailand, digital images available online, including all existing published literature of Curcuma especially in subgenus Curcuma were compared. 


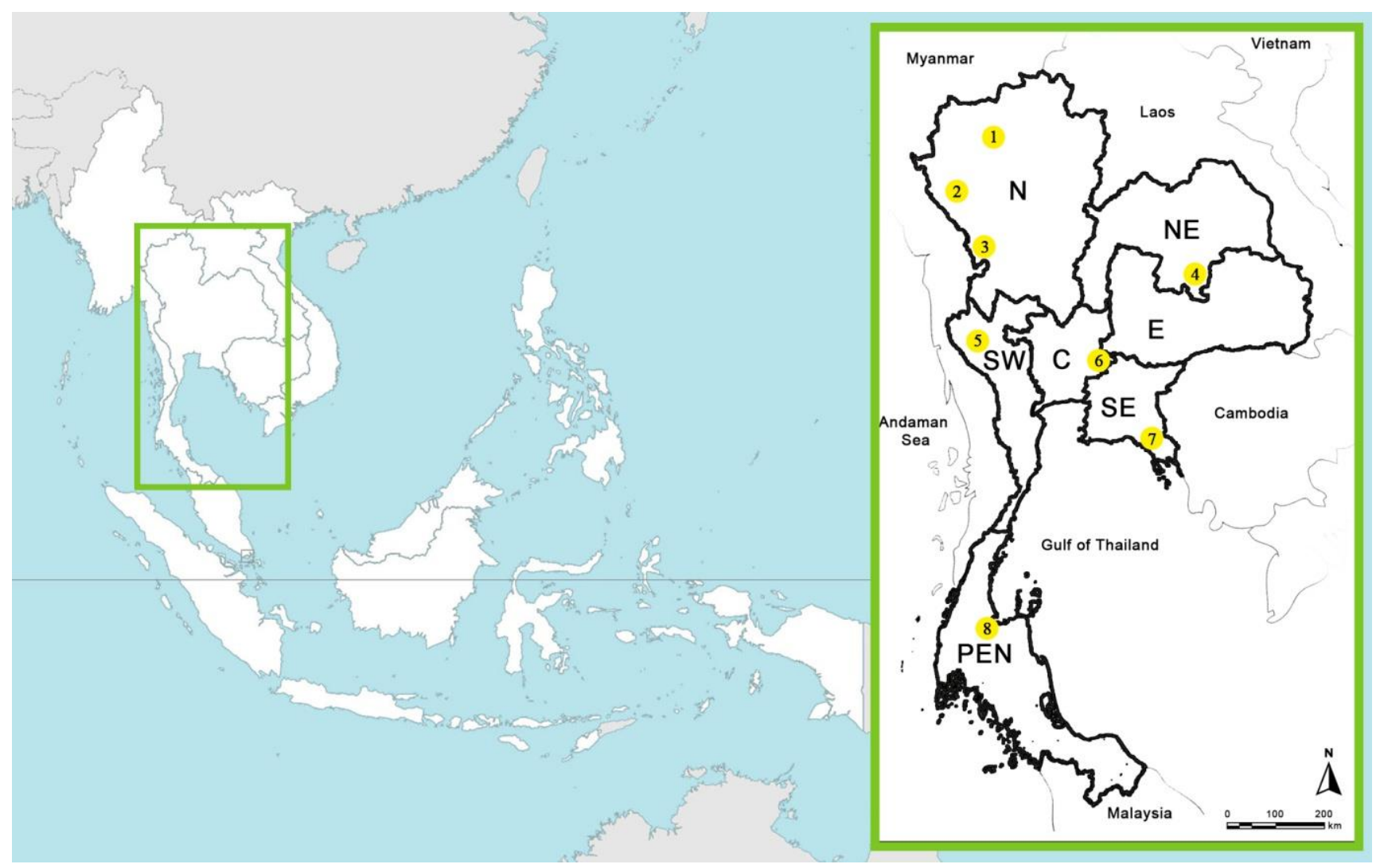

Figure 1. Distribution map of Curcuma wanenlueanga Saensouk, Thomudtha \& Boonma sp. nov. Abbreviations in the map are the floristic region after the "Flora of Thailand" project which $\mathrm{N}=$ Northern, $\mathrm{NE}=$ Northeastern, $\mathrm{SW}=$ Southwestern, $\mathrm{C}=\mathrm{Central}$, E = East, $\mathrm{SE}=$ Southeastern, and PEN = Peninsular. [Chiang Mai (1), Mae Hong Son (2), Tak (3), Maha Sarakham (4), Kanchanaburi (5), Nakhon Nayok (6), Chantaburi (7), and Surat Thani (8)] (source: https://aseanup.com/wp-content/uploads/2015/04/ASEAN-map-whiteblank.jpg).

\section{RESULTS AND DISCUSSION}

During the study of species diversity of the Zingiberaceae for the Flora of Thailand, on 12 October 2019, an undescribed species to science which collected from Mae Hong Son Province and other specimens of this species in cultivation, but all of them did not match with any of the existing taxa. Detailed description, illustrations, photographs, distribution, ecology, and notes (Figures 2-3 and Table 1) have been provided. Additionally, a revised key to 26 species of Curcuma subgenus Curcuma from Thailand is provided for facilitating their identification.

\section{Taxonomic treatment}

Curcuma wanenlueanga Saensouk, Thomudtha \& Boonma, sp. nov. -Figures 2-3, Table 1-subgenus Curcuma

Curcuma wanenlueanga is belonged to the subgenus Curcuma according to the presence of epigynous glands, inflorescence with coma bracts, flowers closed-form, anther spurs acute, and downward-pointed. The morphological description and producing terminal inflorescence of $C$. wanenlueanga make it similar to $C$. longa and $C$. amada, but differ in having leaf adaxially green with reddish-purple along the midrib, leaf-sheath with reddish-brown tinge, whereas $C$. longa and $C$. amada are green without reddish tinge. Moreover, the color and smell of their rhizome can easily distinguishable from each other which $C$. amada has light yellow, white towards the periphery, and smell of green mango while $C$. wanenlueanga has yellow with a darker core internally and C. longa has deep orange-yellow internally, slightly to strongly aromatic respectively without the smell of green mango as in C. amada (Table 1).

Type: THAILAND. Mae Hong Son Province, Sop Moei District, 810 m, 28 August 2017, Boonma 60 (Holotype: KKU!; isotypes: QBG! BKF! BK!)

Perennial herb to $150 \mathrm{~cm}$ tall. Rhizome ovoid, 5.3-8.9 $\times$ $3.8-4.6 \mathrm{~cm}$, externally brown, internally yellow with darker core, 3-4 branch in the opposite side, 5-12 cm long, 1.2$2.5 \mathrm{~cm}$ in diam., each branches rhizome with subbranching, taste bitter slightly aromatic. Roots fleshy. Leafy shoot with 7-10 leaves; pseudostem to $70 \mathrm{~cm}$ long, green with reddish-brown tinge, composed of sheathing bracts and leaf sheaths; sheathing bracts 2-3, apex slightly mucronate; leaf-sheath distichous, green with reddishbrown tinge, pubescent; ligule up to $1 \mathrm{~cm}$ long, bilobed, hyaline, green with a reddish tinge; petiole up to $35 \mathrm{~cm}$ long (petiole of innermost leaves longest, outermost leaf shortest), canaliculate, green with a reddish tinge at the 
base, sparsely pubescent; lamina narrowly lanceolate, 50 $70 \times 15-18 \mathrm{~cm}$, base attenuate, margin entire, apex acuminate, adaxially green with reddish-purple tinge along the midrib (reddish-purple patch may fade when the leaves grow old), abaxially lighter green. Inflorescence terminal appears between the leaf-sheaths; peduncle 30-38 cm long, with up to $1 \mathrm{~cm}$ in diam., pale green to white at the base, pubescent; spike 8-10 cm long, 4-6 cm in diam.; sterile bract 1, apex slightly mucronate, pale green to white at base; coma bracts 5-6, inconspicuous, $2.5-3.2 \times 1.5-2 \mathrm{~cm}$, distal part hooded, apex acute with slightly mucronate, pink at distal part and gradually fade to pale green at the base, fused only at base pubescent; fertile bracts $12-15$ per inflorescence, bract ovate, 3-4.5 × 2-2.6 cm (larger at the base of the inflorescence), margin hyaline, apex acute with slightly mucronate, uppermost with slightly hooded, pubescent, pale green with a reddish tinge at distal part (except veins pale green), connate in the lower $1 / 2$; bracteoles 2 per flower, narrowly obovate-oblong, 2-2.4 $\times$ $0.8-1 \mathrm{~cm}$, apex hooded, mucronate, pubescent, pale greenish-white with pale pink at the apex. Flowers $c .5 \mathrm{~cm}$ long; calyx tubular, 13-15 $\mathrm{mm}$ long, 3-toothed, with unilateral incision up to $8 \mathrm{~mm}$ long, pubescent, pale yellowish-white; floral tube tubular, $3.2-3.5 \mathrm{~cm}$ long, yellow with pink at distal part; dorsal corolla lobe ovate, 14-16 × 9-11 mm, concave, hooded, sparsely hairy, apex mucronate, mucro $c .4 \mathrm{~mm}$ long with fine short hairs, pink; lateral corolla lobes ovate, 13-15 × 8-9 mm, concave, hooded, sparsely hairy, pink; labellum obovate, $15-17 \mathrm{~mm}$ long and 15-16 $\mathrm{mm}$ at widest part apex emarginate, incision to $5 \mathrm{~mm}$, yellow with embossed two darker yellow median band; lateral staminodes irregularly obovate, 11$13 \times 7-8 \mathrm{~mm}$, apex rounded, with short fine hairy on the adaxial side, yellow. Stamen 8-9 mm long; filament c. 4 $\mathrm{mm}$ long, pale yellow, c. $5 \mathrm{~mm}$ broad at base; anther c. 8 $\mathrm{mm}$ long (measured in side-view including spurs), pale yellow, spurred; connective pale yellow; anther spurs $c .4$ $\mathrm{mm}$ long, pale yellow, pointing downwards; anther crest not obvious. Epigynous glands 2, linear, 3-5 mm long, yellowish, apex acute. Style filiform, white, glabrous, placed in the groove in the dorsal side of floral tube; stigma slightly exerted above the anther lobes $1.2-1.3 \times 1.2-1.3$ $\mathrm{mm}$, pale yellowish-white; ostiole ciliate. Ovary trilocular, c. $3 \times 3 \mathrm{~mm}$, pubescent. Fruit and seeds not seen.

Vernacular name: "Wan-En-Lueang" in Thai language.

Phenology: Flowering in July to October; flowers fully open about 5.00-6.00 a.m. and last a single day. Leafy shoot emerging in late April and dormancy begins in late November.
Distribution: Sop Moei District, Mae Hong Son Province, Northern Thailand, and cultivated throughout the country, e.g. Nakhon Nayok, Maha Sarakham, Chiang Mai, Tak, Chantaburi, Suratthani, and Kanchanaburi Provinces (Figure 1).

Habitat: It grows in sandy loam soil and well-drained in the mixed-deciduous forest, at elevation 700-900 m asl.

Etymology: The specific epithet 'wanenlueanga' derived from Thai vernacular name of this species which "wan" means "herbs", "en" means "tendons" referred to its medicinal properties used in traditional medicine to treat beriberi related to tendons and "lueang" means "yellow" referred to its yellow rhizome.

Uses: Thai traditional medicinal use its mature rhizomes which harvest after dormancy (fresh or made it dry powder) combined with other herbs for the treatment of beriberi related to tendons, treatment of paralysis, etc. (Oranuch 2007).

Specimen Examined: THAILAND, Mae Hong Son Province, Sop Moei District, 700 m, Boonma 61 (dry specimen), 19.10.2020 (KKU). Additionally cultivated living specimens and spirit specimens preserved in alcohol: Nakhon Nayok Province, Ban Na District, $10 \mathrm{~m}$. above sea level, Boonma 6, 12.10.2019 (BBRG), Mae Hong Son Province, Mae Sariang District, $900 \mathrm{~m}$, Boonma 62, 20.10.2020 (BBRG), Chiang Mai Province, Chiang Dao District, 850 m, Boonma 63, 27.08.2019 (BBRG), Chantaburi Province, Khlung District, $52 \mathrm{~m}$, Boonma 64, 25.09.2019 (BBRG), Surat Thani Province, Don Sak District, 30 m, Boonma 65, 18.09.2020 (BBRG), and Kanchanaburi Province, Mueang Kanchanaburi District, Boonma 66, 12.08.2020 (BBRG) and cultivated spirit specimens preserved in alcohol from Maha Sarakham Province, Mueang Maha Sarakham District, Thomudtha 1, 05.04.2021 (KKU); Nakhon Nayok Province, Ban Na District, 10 m., Boonma 21, 12.10.2019 (KKU).

Notes: C. wanenlueanga is cultivated and used as a traditional medicine for more than four decades as recorded in a short morphological description and uses in Thai Herb books (Saman and Tassana 1973). In our preliminary survey, only one natural habitat was found in Sop Moei District, Mae Hong Son Province, northern Thailand, and cultivated throughout the country popularly among the collectors of sacred plants and herbs. According to all information about this species is still insufficient information for a proper assessment of conservation status as Data deficient (DD). Further fieldwork and observations are needed to assess changes in population, distribution, and abundance in the future. 

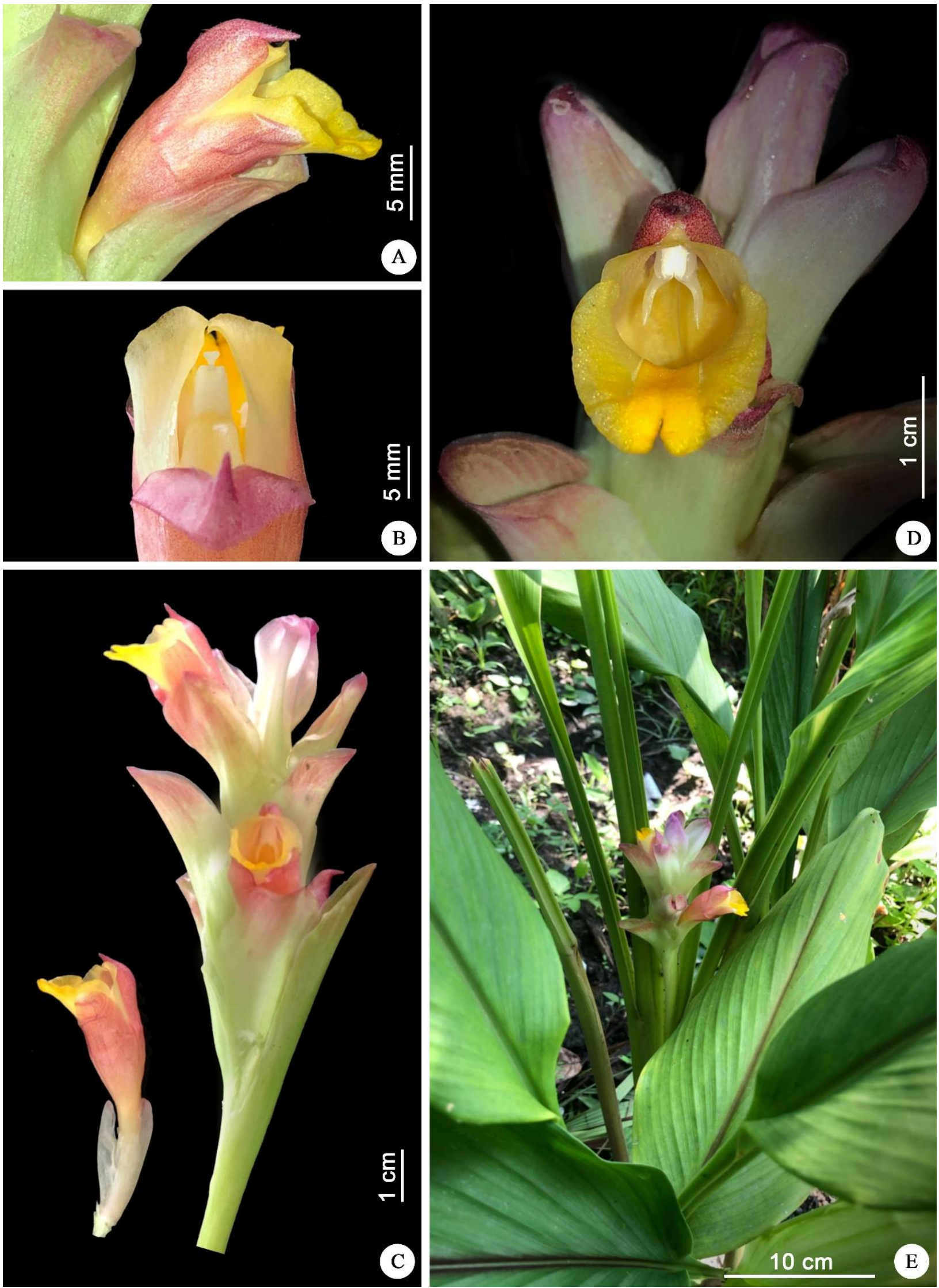

Figure 2. Curcuma wanenlueanga Saensouk, Thomudtha \& Boonma sp. nov. (A) flower-side view, (B) back view of flower with the back view of stamen, (C) flower with bracteoles and inflorescence with flowers-side view, (D) flower-front view, (E) plants in natural habitat in oblique view to show leaf-adaxially with reddish-purple tinge along the midrib and its inflorescence. Photographed by Thawatphong Boonma 


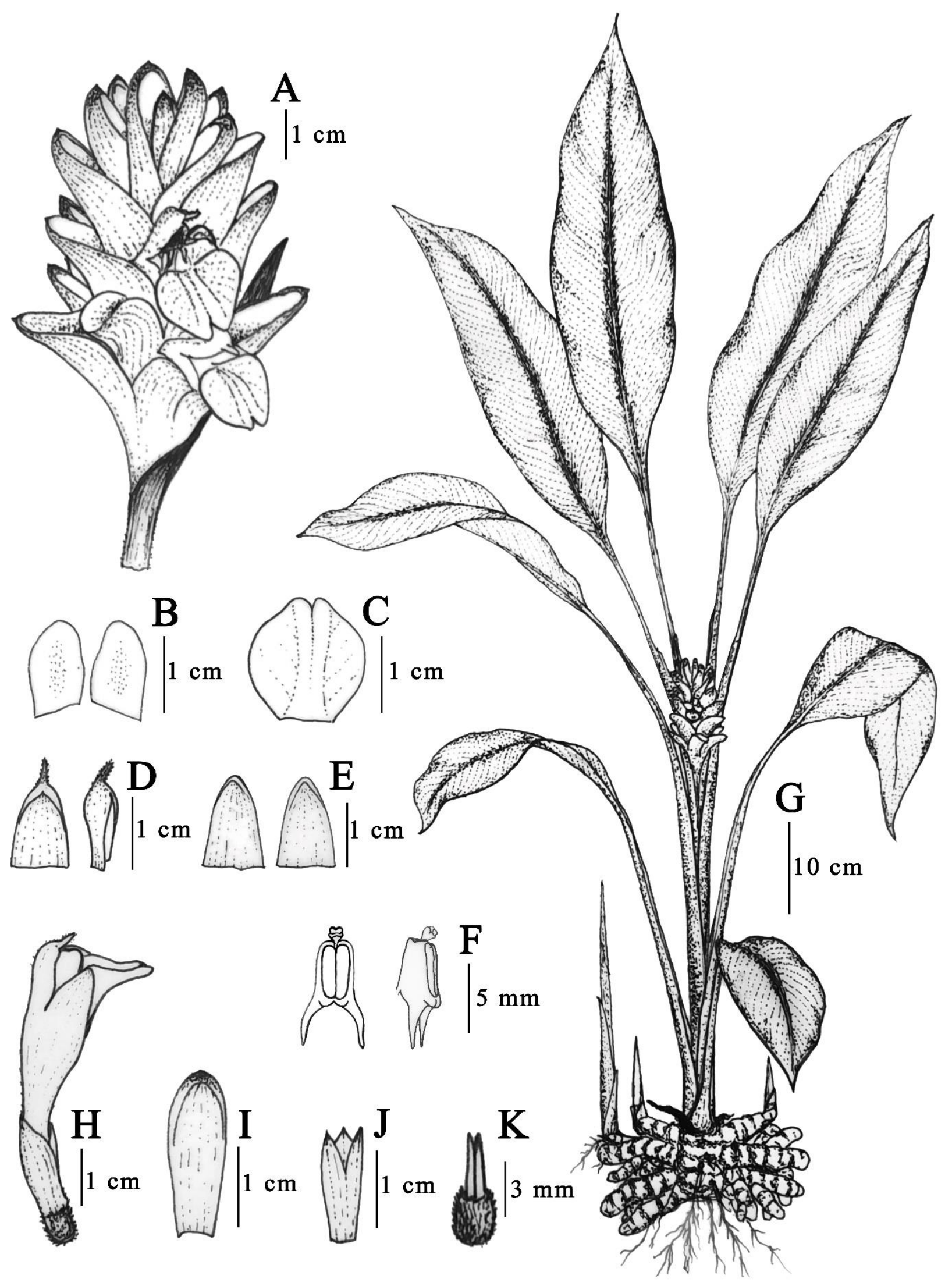

Figure 3. Curcuma wanenlueanga Saensouk, Thomudtha \& Boonma sp. nov. (A) inflorescence with flowers and sterile bract-side view, (B) lateral staminodes, (C) labellum, (D) dorsal corolla lobe-front and side view, (E) lateral corolla lobes, (F) anther-front and side view, (G) habitus, (H) flower with calyx and ovary, (I) bracteoles, (J) calyx, (K) epigynous glands with ovary. Drawn by Thawatphong Boonma 
Table 1. Morphological comparison of Curcuma wanenlueanga, C. longa, and C. amada

\begin{tabular}{|c|c|c|c|}
\hline Characters & Curcuma wanenlueanga & $\begin{array}{l}\text { Curcuma longa } \\
\text { (Sabu 2006) }\end{array}$ & $\begin{array}{l}\text { Curcuma amada } \\
\text { (Roxburgh 1810; Sabu 2006) }\end{array}$ \\
\hline Rhizome & large size, $5.3-8.9 \times 3.8-4.6 \mathrm{~cm}$ & medium size, $2-3 \times 2-3 \mathrm{~cm}$ & large size, $4-5.3 \times 3-4 \mathrm{~cm}$ \\
\hline Rhizome internally & yellow with darker core & deep orange-yellow & $\begin{array}{l}\text { light yellow, white towards the } \\
\text { periphery }\end{array}$ \\
\hline Rhizome-smell & slightly aromatic & strongly aromatic & smell of green mango \\
\hline Pseudostem & $\begin{array}{l}\text { to } 70 \mathrm{~cm} \text { tall, green with reddish- } \\
\text { brown tinge }\end{array}$ & c. $30 \mathrm{~cm}$ tall, green & $30-35 \mathrm{~cm}$ tall, green \\
\hline Leaf-sheath & $\begin{array}{l}\text { pubescent, green with reddish- } \\
\text { brown tinge }\end{array}$ & glabrous, green & glabrous, green \\
\hline Leaves-number & $7-10$ & $4-6$ & $4-6$ \\
\hline Petiole & $\begin{array}{l}\text { up to } 35 \mathrm{~cm} \text { long, sparsely } \\
\text { pubescent, green with a reddish } \\
\text { tinge at base }\end{array}$ & $35-40 \mathrm{~cm}$ long, glabrous, green & 5-10 cm long, glabrous, green \\
\hline Lamina-shaped & narrowly lanceolate & oblong-lanceolate & oblong, lanceolate, acuminate \\
\hline Lamina-size & $50-70 \times 15-18 \mathrm{~cm}$ & $45-60 \times 15-20 \mathrm{~cm}$ & $45-60 \times 14-15 \mathrm{~cm}$ \\
\hline Lamina-margin & entire, glabrous & $\begin{array}{l}\text { wavy, pubescent towards the } \\
\text { extreme tip }\end{array}$ & entire, glabrous \\
\hline Lamina-adaxially & $\begin{array}{l}\text { green with reddish-purple tinge } \\
\text { along the midrib }\end{array}$ & green & green \\
\hline Inflorescence & terminal & terminal & terminal and lateral \\
\hline Peduncle & $30-38 \mathrm{~cm}$ long & $15 \mathrm{~cm}$ long & $20-22 \mathrm{~cm}$ long \\
\hline Spike & $8-10 \mathrm{~cm}$ long & $8-10 \mathrm{~cm}$ long & $12-18 \mathrm{~cm}$ long \\
\hline Coma-number & $4-6$ & $8-10$ & $5-8$ \\
\hline Coma-size & $2.5-3.2 \times 1.5-2 \mathrm{~cm}$ & $7 \times 3.5 \mathrm{~cm}$ & c. $6 \times 2.5 \mathrm{~cm}$ \\
\hline Coma-apex & hooded & not hooded & not hooded \\
\hline Coma-color & $\begin{array}{l}\text { pink at distal part and gradually } \\
\text { fade to pale green at base }\end{array}$ & white & light violet \\
\hline Fertile bract & $12-15$ per inflorescence & 25-30 per inflorescence & 15-18 per inflorescence \\
\hline Bract-size & $3-4.5 \times 2-2.6 \mathrm{~cm}$ & $4.5-5.5 \times 3-5 \mathrm{~cm}$ & c. $4 \times 3.5 \mathrm{~cm}$ \\
\hline Bract-color & $\begin{array}{l}\text { pale green with reddish tinge at } \\
\text { distal part, veins pale green }\end{array}$ & pale green & green \\
\hline Bract-connate & lower $1 / 2$ & lower $1 / 2$ & lower $2 / 3$ \\
\hline Flowers & 1 per bract & $1-2$ per bract & 4-5 per bract \\
\hline Bracteoles & pubescent & glabrous & minutely hairy \\
\hline Flowers & $\begin{array}{l}\text { c. } 5 \mathrm{~cm} \text { long } \\
\text { longer than bracts }\end{array}$ & $\begin{array}{l}4.5-5.5 \mathrm{~cm} \text { long } \\
\text { equal to the bracts }\end{array}$ & $\begin{array}{l}\text { c. } 5 \mathrm{~cm} \text { long } \\
\text { longer than bracts }\end{array}$ \\
\hline Calyx & $13-15 \mathrm{~mm}$ long & $10 \mathrm{~mm}$ long & $10 \mathrm{~mm}$ long \\
\hline Floral tube & $3.2-3.5 \mathrm{~cm}$ long & $2.5 \mathrm{~cm}$ long & $3 \mathrm{~cm}$ long \\
\hline Floral tube-color & yellow with pink at distal part & white & pale yellow \\
\hline Dorsal corolla lobe & pink & white & white \\
\hline Lateral corolla lobe & pink, sparsely hairy & white, glabrous & white, glabrous \\
\hline Staminodes-size & $11-13 \times 7-8 \mathrm{~mm}$ & $1.5 \times 0.8 \mathrm{~cm}$ & c. $1.5 \times 0.9 \mathrm{~cm}$ \\
\hline Staminodes-color & yellow & pale yellow & pale yellow \\
\hline Anther spurs & c. $4 \mathrm{~mm}$ long & $3 \mathrm{~mm}$ long & $1-2 \mathrm{~mm}$ long \\
\hline Epigynous glands & $3-5 \mathrm{~mm}$ long & $5 \mathrm{~mm}$ long & $6 \mathrm{~mm}$ long \\
\hline Ovary & $3 \mathrm{~mm}$ long, pubescent & $5 \mathrm{~mm}$ long, pubescent & $3 \mathrm{~mm}$ long, densely hairy \\
\hline Stigma & $\begin{array}{l}\text { slightly exerted above the anther } \\
\text { lobes }\end{array}$ & $\begin{array}{l}\text { closely appressed within the } \\
\text { anther lobes }\end{array}$ & $\begin{array}{l}\text { closely appressed within the } \\
\text { anther lobes }\end{array}$ \\
\hline
\end{tabular}

\section{Key to 26 species of Curcuma subgenus Curcuma in Thailand}

1. Rhizome branches not produced

2. Inflorescence lateral and terminal

C. angustifolia

2. Inflorescence terminal

3. Sheaths glabrous; leaf abaxially glabrous

3. Sheaths pubescent; leaf abaxially hairy or glabrescent at least at the apex

1. Rhizome branches produced or well developed

4. Inflorescence terminal

5. Rhizome creeping

C. rubrobracteata

5. Rhizome with branches non-creeping

6. Anther ecalcarate

7. Flowers yellow or orange-yellow

7. Flowers cream-white with yellow in the center of labellum 
6. Anther calcarate

8. Bracts glabrous

9. Ovary glabrous

9. Ovary pubescent

C. antinaia

8. Bracts pubescent

10. Coma bracts greenish-white

10. Coma bracts pink or white with pink at tip

11. Peduncle red

11. Peduncle green

12. Ovary glabrous

12. Ovary pubescent

C. sattayasaiorum

13. Leaf adaxially green with reddish-purple along the midrib

13. Leaf adaxially green with green midrib

14. Rhizome pale yellow with the smell of green mango

C. viridiflora

C. phrayawan

C.petiolata

14. Rhizome deep orange-yellow, strongly aromatic, without smell of green mango

4. Inflorescence usually lateral

15. Leaves lower surface pubescent

16. Leaf-adaxially green with green midrib

17. Rhizome yellow; lamina broadly lanceolate

17. Rhizome pale yellow; lamina oblong

16. Leaf-adaxially green with red or reddish-purple patch along midrib

18. Bracts glabrous

18. Bracts pubescent

19. Inflorescence cylindrical $>10 \mathrm{~cm}$ long; bracts green, short-hairy on both surfaces

19. Spike almost globular shape $<10 \mathrm{~cm}$ long; bract bright green to brownish green with palegreen venation, adaxially puberulent, abaxially glabrous

C. wanenlueanga

C. amada

C. longa

15. Leaves lower surface glabrous

20. Petioles and leaf-sheaths reddish-brown

20. Petioles and leaf-sheaths green

21. Leaf-adaxially green with red or reddish-purple patch along the midrib

22. Rhizome aeruginous green

22. Rhizome yellow or orange

23. Corolla lobes nearly white or with very slight pinkish shade; rhizome pale straw to yellowish white

C. aromatica

C. elata

C. zedoarioides

C. latifolia

C. globulifera

C. rubescens

23. Corolla lobes conspicuously pink to reddish; rhizome deep bright orange to yelloworange

C. zanthorrhiza

21. Leaf-adaxially green without red patch along midrib

24. Fertile bracts pale pink; rhizome pale ochraceous

C. comosa

24. Fertile bracts green; rhizome white to pale yellow

25. Bracts glabrous

25. Bracts minutely puberulous on both sides

C. leucorrhiza

C. manga

\section{ACKNOWLEDGMENTS}

This research project is financially supported by Mahasarakham University. We thank Walai Rukhavej Botanical Research Institute, Mahasarakham University, Mahasarakham Hospital, Brio Garden (BBRG), and our family for their facilities during this study.

\section{REFERENCES}

Araujo CC, Leon LL. 2001. Biological activities of Curcuma longa L. Mem Inst Oswaldo Cruz 96:723-728.

Larsen K, Larsen SS. 2006. Gingers of Thailand. Queen Sirikit Botanic Garden, The Botanical Garden Organization, Chiang Mai.

Leong-Škorničková J, Šida O, Záveská E, Marhold K. 2015. History of infrageneric classification, typification of supraspecific names and outstanding transfers in Curcuma (Zingiberaceae). Taxon 64 (2): $362-373$.

Oranuch K. 2007. Herb in Zingiberaceae. Biotechnology Research and Development office, Bangkok.

Roxburgh W. 1810. Descriptions of several of the Monandrous Plants of India (Curcuma). Asiatic Researches 11: 329-342.

Sabu M. 2006. Zingiberaceae and Costaceae of South India. Indian Association for Angiosperm Taxonomy, Calicut University, Kerala.

Saensouk S, Boonma T, Saensouk P. 2021. Six new species and a new record of Curcuma L. (Zingiberaceae) from Thailand. Biodiversitas 22(4): 1658-1685.

Sirirugsa P, Larsen K, Maknoi C. 2007. The genus Curcuma L. (Zingiberaceae): Distribution and classification with reference to species diversity in Thailand. Gardens' Bull Singapore 59 (1\&2): 203-220.

Záveská E, Fér T, Šida O, Krak K, Marhold K, Leong-Škorničková J. 2012. Phylogeny of Curcuma (Zingiberaceae) based on plastid and nuclear sequences: Proposal of the new subgenus Ecomata. Taxon 61 (4): 747-763 